\title{
Long-term Changes in the Fish Assemblage in Sandybeach Lake, Northern Ontario, Following the Introduction of Rainbow Smelt (Osmerus mordax)
}

\author{
SCOTt M. ReID ${ }^{1,3}$ and DunCAN B. WAIN ${ }^{2}$ \\ ${ }^{1}$ Aquatic Research and Monitoring Section, Ontario Ministry of Natural Resources and Forestry, Trent University - DNA \\ Building, 1600 West Bank Drive, Peterborough, Ontario K9L 0G2 Canada \\ ${ }^{2}$ P.O. Box 272, Grp 327 RR \#3, Selkirk, Manitoba R1A 2A8 Canada \\ ${ }^{3}$ Corresponding author: reid.scott@ontario.ca
}

Reid, Scott M., and Duncan B. Wain. 2016. Long-term changes in the fish assemblage in Sandybeach Lake, northern Ontario, following the introduction of Rainbow Smelt (Osmerus mordax). Canadian Field-Naturalist 130(4): 344-350.

Rainbow Smelt (Osmerus mordax, Mitchill, 1814) has been widely introduced into lakes across North America and are reported to have an adverse effect on native fishes. In this study, we investigated the long-term changes to the pelagic fish assemblage in a northwestern Ontario lake (Sandybeach Lake) after Rainbow Smelt were introduced in the 1980s. We repeated an earlier summer, pelagic gill-netting survey of Sandybeach Lake and a nearby reference lake (Little Vermillion Lake) that does not contain Rainbow Smelt. Fishes throughout the water column were sampled with overnight sets of 5.2-m-deep, multi-mesh horizontal gill-nets. Compared with 1990 pelagic sampling, native fishes were significantly less abundant, less diverse, and largely absent from the deeper parts of Sandybeach Lake in 2012. Cisco (Coregonus artedi, Lesueur, 1818), Emerald Shiner (Notropis atherinoides Rafinesque, 1818), and Lake Whitefish (Coregonus clupeaformis, Mitchill, 1814) were notably absent in 2012. In contrast, Rainbow Smelt remained abundant at all depths sampled. A small number of ciscoes — including Shortjaw Cisco (Coregonus zenithicus (Jordan and Evermann, 1909)) — and Lake Whitefish were captured from benthic gill-nets. Based on the lack of ciscoes in pelagic gill-nets, the very old ages (mean 30 years) of the few individuals captured in benthic gill-nets, and a severely skewed sex ratio, it is highly likely that ciscoes will be extirpated from Sandybeach Lake. Although the composition of the pelagic fish assemblage differed between years, Cisco was still abundant in Little Vermillion Lake with the presence of young individuals indicating ongoing recruitment.

Key Words: Lake; invasive species; introduction; impact; Cisco; Coregonus artedi; Lake Whitefish; Coregonus clupeaformis; Rainbow Smelt; Osmerus mordax

\section{Introduction}

The Rainbow Smelt (Osmerus mordax, Mitchill, 1814) is a small (up to $20 \mathrm{~cm}$ long), elongate, and laterally compressed anadromous fish that was historically limited to the Atlantic coastal drainage of eastern North America (Scott and Crossman 1973). As a result of human transfers and natural dispersal, the species' distribution in Canada has expanded to include the Laurentian Great Lakes and inland lakes in Manitoba and Ontario (Franzin et al. 1994). Model-based forecasts indicate the potential for Rainbow Smelt to spread into thousands more inland Ontario lakes, almost all of which support fish species known to be adversely affected by Rainbow Smelt (Mercado-Silva et al. 2006). Once introduced, Rainbow Smelt often establish large populations and can have a negative effect on native fishes through competition for zooplankton and predation of larval fish (Loftus and Hulsman 1986; Evans and Loftus 1987; Myers et al. 2009). Cisco (Coregonus artedi, Lesueur, 1818) and Lake Whitefish (Coregonus clupeaformis, Mitchill, 1814) are two inland lake species that have shown rapid declines following Rainbow Smelt establishment in small, northern temperate lakes (Evans and Loftus 1987; Hrabik et al. 1998).

Following the 1989 confirmation of Rainbow Smelt in Sandybeach Lake (also known as Big Sandy Lake), Wain (1993) undertook a study of their initial impacts on oligotrophic lake fishes. Conducted within several years of colonization, a high degree of diet and habitat overlap between Rainbow Smelt and ciscoes and corresponding negative demographic impacts on Cisco were reported. Shifts in the spatial distribution of Yellow Perch (Perca flavescens (Mitchill, 1814)) from pelagic to littoral habitats were also inferred. The study also provided the first record of Shortjaw Cisco (Coregonus zenithicus (Jordan and Evermann, 1909)) from Sandybeach Lake.

A member of the formerly diverse Great Lakes cisco flock, the Shortjaw Cisco has been assessed as threatened in Ontario (MNRF 2016) and Canada (COSEWIC 2015). Invasive species are considered a significant threat affecting Canadian freshwater fishes at risk (Dextrase and Mandrak 2006). Rainbow Smelt has been introduced into most of the lakes in Ontario and Manitoba that are known to support Shortjaw Cisco (SCRT 
2005). Etnier and Skelton (2003) have suggested that Rainbow Smelt may be responsible for Shortjaw Cisco declines in Lake Saganaga and for a more poorly differentiated present-day cisco fauna in Lake Nipigon than described in the early 1900s. However, direct effects are not well understood, but may include predation, competition, and food web disruption (SCRT 2005). An improved understanding of the risk to Shortjaw Cisco associated with Rainbow Smelt invasions is important for recovery efforts and future status assessments.

In 2012 and 2013, we completed a summer, gill-net survey of Sandybeach Lake in northwestern Ontario and a nearby reference lake without Rainbow Smelt (Little Vermillion Lake) to confirm the presence of Shortjaw Cisco in Sandybeach Lake and characterize the long-term ( $>20$ years) impact of Rainbow Smelt on ciscoes and other native fishes.

\section{Study Site}

Our research was done in two oligotrophic lakes near Dryden, Ontario. Sandybeach Lake ( $\left.49^{\circ} 49^{\prime} \mathrm{N}, 92^{\circ} 21^{\prime} \mathrm{W}\right)$ has a surface area of 3803 ha, a mean depth of $20.3 \mathrm{~m}$, and a maximum depth of $41.0 \mathrm{~m}$; it is $35 \mathrm{~km}$ east of Dryden. Little Vermillion Lake $\left(50^{\circ} 00^{\prime} \mathrm{N}, 92^{\circ} 11^{\prime} \mathrm{W}\right)$ has a surface area of $2292 \mathrm{ha}$, a mean depth of $9.6 \mathrm{~m}$, and a maximum depth of $26.0 \mathrm{~m}$; it is $45 \mathrm{~km}$ northeast of Dryden. Both lakes are located in headwater areas of the English River drainage and support similar fish assemblages, including Cisco, Emerald Shiner (Notropis atherinoides Rafinesque, 1818), Lake Whitefish, Lake Trout (Salvelinus namaycush (Walbaum, 1792)), Ninespine Stickleback (Pungitius pungitius (L., 1758)), Spottail Shiner (Notropis hudsonius (Clinton, 1824)), White Sucker (Catostomus commersonii (Lacepède, 1803)), and Yellow Perch. Rainbow Smelt are not present in Little Vermillion Lake. The first report of Rainbow Smelt from lakes in the Dryden area was in 1962 (Campbell et al. 1991).

\section{Methods}

Fish Sampling

We sampled Sandybeach Lake on 14-19 August 2012 and Little Vermillion Lake on 9-13 August 2013. Sampling occurred four and two weeks later in the calendar year, respectively, than in 1990 (Wain 1993). At the time of sampling, thermoclines were well established in both lakes: in Sandybeach Lake, at a depth of $11-13 \mathrm{~m}$ from the water surface; in Little Vermillion Lake, $8-9 \mathrm{~m}$. Above the thermocline (i.e., the epilimnion), water temperatures were $18-21^{\circ} \mathrm{C}$ in Sandybeach Lake and $17-19^{\circ} \mathrm{C}$ in Little Vermillion Lake. Below the thermocline (i.e., the hypolimnion), mean water temperature was $7.7^{\circ} \mathrm{C}$ in Sandybeach Lake and $7.0^{\circ} \mathrm{C}$ in Little Vermillion Lake.

We used the same net design and randomized depthstratified sampling approach as Wain (1993). We sampled fishes in the pelagic zone of both lakes with 5.2- m-deep pelagic horizontal gill-nets consisting of 6-m panels of 6.25-, 8-, 10-, 12.5-, and 16-mm mesh (total net length $30 \mathrm{~m}$ ). In both lakes, nets were suspended in the water column at the following four depth strata: $0.9-6.1 \mathrm{~m} ; 6.1-11.3 \mathrm{~m} ; 11.3-16.5 \mathrm{~m}$; and $16.5-21.7 \mathrm{~m}$. For all depth strata, six nets were set at locations where the lake was $22 \mathrm{~m}$ deep. In Sandybeach Lake, six additional nets were set at each of the two upper depth strata where the lake was $12 \mathrm{~m}$ deep and at a depth stratum of 32-37.2 $\mathrm{m}$ where the lake was $39 \mathrm{~m}$ deep. The total number of overnight gill-net sets was 42 in Sandybeach Lake and 24 in Little Vermillion Lake.

At both lakes, overnight net sets were in place longer than in 1990. At Sandybeach Lake, the mean duration of net sets was $13.1 \mathrm{~h}(9.1 \mathrm{~h}$ in 1990). The mean duration of net sets at Little Vermillion Lake was $15.2 \mathrm{~h}$ (9.0 h in 1990).

To improve Shortjaw Cisco detection, we also sampled Sandybeach Lake with overnight sets of $1.83-\mathrm{m}-$ deep, benthic gill-nets consisting of 15-m panels of 25-, 38-, and 51-mm mesh (total net length $45 \mathrm{~m}$ ). Thirtyone net sets were placed between 9 and 24 August 2012 at a range of water depths (24-41 m, mean $36 \mathrm{~m})$.

We froze ciscoes for later processing in the laboratory. To interpret whether Sandybeach Lake ciscoes were Cisco or Shortjaw Cisco, we counted gill rakers and examined jaw morphology (Hubbs et al. 2004). For fish from both lakes, we examined gonads to determine whether individual cisco were female or male. Using otoliths, we interpreted the ages of all Sandybeach Lake cisco $(n=33)$ and a sub-sample $(n=47)$ of Little Vermillion Lake cisco. Annuli from transverse sections of otoliths were interpreted using a compound microscope with reflected light (Muir et al. 2008).

\section{Data Analysis}

Before analysis, we standardized gill-net catch data by duration (hours) of each net set (catch-per-unit effort, CPUE). Catch was standardized by duration of each set because gill-net sets in Sandybeach Lake were 30\% longer in 2012 than in 1990 and 40\% longer in Little Vermillion Lake in 2013 than in 1990. For each lake, we tested for differences between years in terms of native fish CPUE (number of individuals captured per hour) and native species richness (number of species captured per hour) using the non-parametric MannWhitney test (Sokal and Rohlf 1995). In addition, for each lake, we tested whether the structure of the native fish assemblage differed between years using the non-parametric multivariate test, analysis of similarity (ANOSIM; Clarke 1993). ANOSIM was done with sample-by-species matrices of log-transformed abundance data and the Bray-Curtis dissimilarity measure. Catch data from all depth strata were pooled for these statistical tests. To examine whether between-year differences varied with depth sampled, we calculated native fish CPUE and species diversity (Shannon-Weiner index) for each depth stratum. We used $95 \%$ confidence intervals to identify significant differences be- 
tween years. The between-year similarity of fish assemblages within depth strata was characterized using the Bray-Curtis dissimilarity measure (Legendre and Legendre 1998), which is bounded by zero and one, where zero indicates samples share all the same species and one indicates samples do not share any species. For all analysis, we excluded Rainbow Smelt from datasets.

Statistical analysis was completed using PAST version 1.94 (Hammer et al. 2001).

\section{Results}

Sandybeach Lake

In 2012 using pelagic gill-nets, we captured 3821 fish representing nine species. Mean native species CPUE ( $81 \%$ less) and richness ( $52 \%$ less) were significantly lower in 2012 than 1990 (Mann-Whitney test: CPUE $U=378, P<0.001$; richness $U=444, P<0.001$; Figure 1). The structure of the fish assemblage also differed between years (ANOSIM: $R=0.38, P<$ 0.001 ). Five of the nine species found in 1990 were not collected in 2012, including previously abundant Cisco and Emerald Shiner (Table 1). Smallmouth Bass (Micropterus dolomieu (Lacepède, 1802)) and Ninespine Stickleback, which were not captured in 1990 , were moderately abundant in 2012. Compared with 1990, Rainbow Smelt CPUE declined by 56\%; however, this species still represented $94 \%$ of fishes collected in 2012 and it was found in all gill-net sets. During both years, the largest numbers of Rainbow Smelt were captured from the 6.1-11.3 m depth stratum (Figure 2).

Across all depth strata, mean CPUE of native fishes was lower in 2012 than 1990 (Table 2). However, only differences at the shallowest and deepest depths were considered significant. Differences were a result of the absence, in 2012, of previously abundant Emerald Shiner from the upper depth stratum and Cisco from the deepest stratum (Figure 2). At all depths, native fish assemblages from 1990 and 2012 were dissimilar (Table 2). Compared with 1990, substantive declines in native species diversity (and number of species detected) were evident at the deepest stratum sampled in 2012. In 1990, the mean number of native species caught in pelagic nets set at $32.0-37.2 \mathrm{~m}$ was 1.5 species. No native species were caught in 2012 at this depth.

We captured 33 ciscoes with the larger-mesh, benthic gill-nets. Other fishes captured included Rainbow Smelt $(n=261)$, Lake Whitefish $(n=47)$, Mottled Sculpin (Cottus bairdii Girard, 1850; $n=22$ ), White Sucker $(n=9)$, Lake Trout $(n=3)$, and Burbot (Lota lota (L., $1758) ; n=2)$. For 13 of the ciscoes collected, low gill raker counts $(n=37-39)$ and short lower jaws were consistent with descriptions of Shortjaw Cisco (Hubbs et al. 2004). Gill raker counts of other ciscoes were higher $(n=40-43)$ and lower jaws were either terminal or extended. In 2012, the mean age of ciscoes was 30.4 years (range 19-35 years) and mean total length was $300.1 \mathrm{~mm}$ (range $222-345 \mathrm{~mm}$ ). The sex ratio of ciscoes was severely skewed ( 27 female: 2 male). Cis-
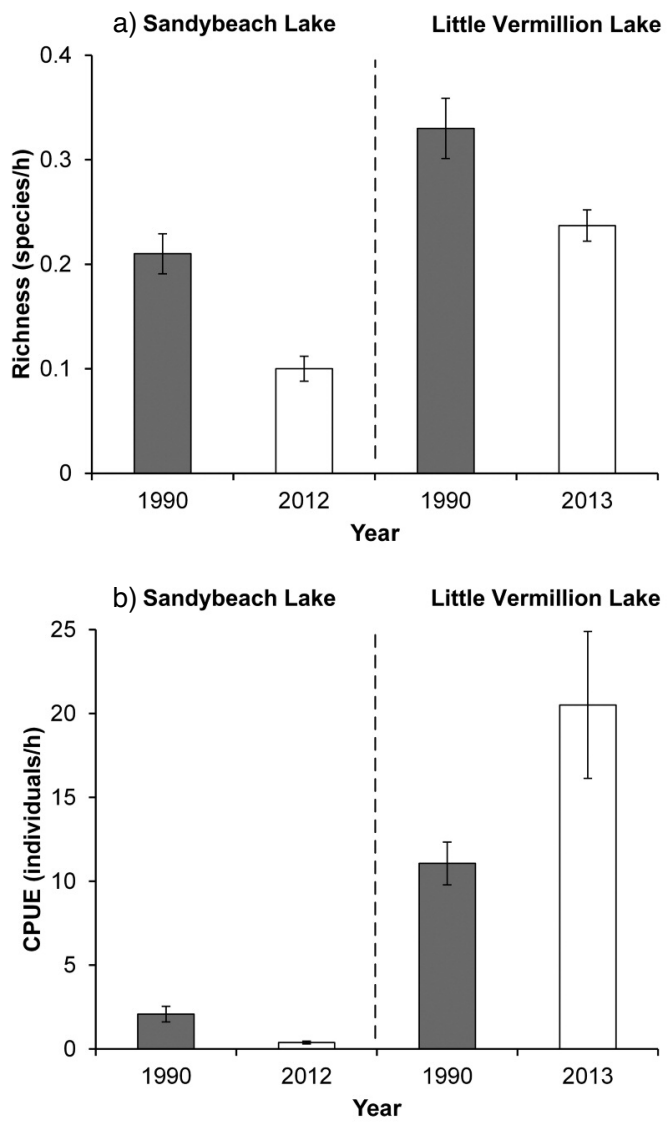

FIGURE 1. Between-year differences in native fish species richness (a) and catch-per-unit effort (CPUE; b) based on catches from summer, pelagic gill-net sets in Sandybeach Lake, where Rainbow Smelt (Osmerus mordax) were present, and Little Vermillion Lake, without Rainbow Smelt. Mean values and standard errors (SE) are presented.

coes netted in 1990 were smaller, with total lengths between 97 and $251 \mathrm{~mm}$ (Wain 1993). Mean total length of Lake Whitefish captured in 2012 was $538 \mathrm{~mm}$ (range 477-618 mm).

\section{Little Vermillion Lake}

In 2013, we captured 7026 fish representing eight species. The mean native species richness at Little Vermillion Lake was significantly lower (28\% less) in 2013 than 1990 (Mann-Whitney test: $U=156, P<0.001$; Figure 1). The structure of the Little Vermillion Lake fish assemblage also differed between years (ANOSIM: $R=0.18, P<0.001$ ). Two of the nine species detected in 1990 were not collected in 2013, including Bluntnose Minnow (Pimephales notatus (Rafinesque, 1820)) and Emerald Shiner (Table 1). Mean CPUE increased by 85.4\% from 1990 to 2013, reflecting the greater abundance of Cisco and Yellow Perch. However, the dif- 
TABLE 1. Between-year comparison of the composition and mean catch-per-unit effort (CPUE, number/h) of species captured in pelagic gill-nets in Sandybeach Lake where Rainbow Smelt (Osmerus mordax) were present and Little Vermillion Lake where they were absent, northern Ontario.*

\begin{tabular}{|c|c|c|c|c|}
\hline \multirow[b]{2}{*}{ Species } & \multicolumn{2}{|c|}{ Composition, $\%$} & \multicolumn{2}{|c|}{ CPUE, mean (SE) } \\
\hline & 1990 & 2012 & 1990 & 2012 \\
\hline \multicolumn{5}{|l|}{ SANDYBEACH LAKE } \\
\hline Burbot (Lota lota) & $<0.1$ & 0.0 & $<0.10$ & 0.00 \\
\hline Cisco (Coregonus artedi) & 2.6 & 0.0 & $0.56(0.09)$ & 0.00 \\
\hline Deepwater Sculpin (Myoxocephalus thompsonii) & $<0.1$ & 0.0 & $<0.10$ & 0.00 \\
\hline Emerald Shiner (Notropis atherinoides) & 5.8 & 0.0 & $1.06(0.29)$ & 0.00 \\
\hline Lake Trout (Salvelinus namaycush) & $<0.1$ & 0.2 & $<0.10$ & $<0.10$ \\
\hline Mottled Sculpin (Cottus bairdii) & $<0.1$ & 0.0 & $<0.10$ & 0.00 \\
\hline Ninespine Stickleback (Pungitius pungitius) & 0.0 & 1.5 & 0.00 & $<0.10$ \\
\hline Northern Pike (Esox lucius) & $<0.1$ & 0.2 & $<0.10$ & $<0.10$ \\
\hline Rainbow Smelt (Osmerus mordax) & 88.4 & 94.3 & $15.50(3.34)$ & $6.80(0.93)$ \\
\hline Smallmouth Bass (Micropterus dolomieu) & 0.0 & 0.5 & 0.00 & $<0.10$ \\
\hline Spottail Shiner (Notropis hudsonius) & 2.9 & 2.6 & $0.60(0.48)$ & $0.17(0.063)$ \\
\hline Troutperch (Percopsis omiscmaycus) & $<0.1$ & 0.6 & $<0.10$ & $<0.10$ \\
\hline Walleye (Sander vitreus) & 0.0 & $<0.1$ & 0.00 & $<0.10$ \\
\hline Yellow Perch (Perca flavescens) & 0.0 & $<0.1$ & 0.00 & $<0.10$ \\
\hline Species & 1990 & 2013 & 1990 & 2013 \\
\hline \multicolumn{5}{|l|}{ LiTTLE VERMILLION LAKE } \\
\hline Bluntnose Minnow (Pimephales notatus) & $<0.1$ & 0.0 & $<0.10$ & 0.00 \\
\hline Cisco (Coregonus artedi) & 62.5 & 38.7 & $6.60(1.13)$ & $7.37(1.23)$ \\
\hline Emerald Shiner (Notropis atherinoides) & 7.4 & 0.0 & $0.89(0.41)$ & 0.00 \\
\hline Lake Trout (Salvelinus namaycush) & $<0.1$ & 0.4 & $<0.10$ & $<0.10$ \\
\hline Lake Whitefish (Coregonus clupeaformis) & 1.2 & 0.3 & $0.13(0.08)$ & $<0.10$ \\
\hline Ninespine Stickleback (Pungitius pungitius) & 3.7 & 0.1 & $0.44(0.41)$ & $<0.10$ \\
\hline Northern Pike (Esox lucius) & $<0.1$ & $<0.1$ & $<0.10$ & $<0.10$ \\
\hline Smallmouth Bass (Micropterus dolomieu) & 0.0 & $<0.1$ & 0.00 & $<0.10$ \\
\hline Spottail Shiner (Notropis hudsonius) & 1.4 & $<0.1$ & $0.17(0.13)$ & $<0.10$ \\
\hline Yellow Perch (Perca flavescens) & 23.6 & 60.4 & $2.80(1.01)$ & $12.96(4.51)$ \\
\hline
\end{tabular}

*Total number of fishes captured: Sandybeach Lake, $1990=2315,2012=3821$; Little Vermillion Lake, $1990=6791,2013$ $=7026$.

Note: $\mathrm{SE}=$ standard error.

ference between years was not significant (MannWhitney test: $P=0.38)$. In both years, Cisco $(n=2716)$ and Yellow Perch $(n=4244)$ represented more than $94 \%$ of the pelagic gill-net catch (Table 1). Cisco was collected from all gill-net sets, and Yellow Perch was collected from $83 \%$ of gill-net sets. Most Yellow Perch were collected from the upper depth stratum, while most Cisco were collected from the intermediate depth strata (Figure 2). Compared with 1990, there was a large increase in the number of gill-nets that captured Lake Trout (16 nets in 2013 versus one net in 1990).

Significantly more fish were collected from the two upper depth strata in 2013 than 1990. Fewer fish were collected from the deepest level sampled (Table 2). At all depths, native fish assemblages from 1990 and 2013 were substantially more similar than observed at Sandybeach Lake (Table 2). Differences in species composition between years were most evident at the top depth stratum (0.9-6.0 m) where, in 2013, formerly abundant Emerald Shiner was absent (Figure 2) and 85\% fewer Spottail Shiner were captured. Compared with 1990 , large increases in native species diversity were evident at the two deepest strata sampled in 2013: 11.3-
$16.5 \mathrm{~m}$ and $16.5-21.7 \mathrm{~m}$. Although the total number of species detected at these depths was similar, species were more frequently detected by each gill-net in 2013 (mean 3.25 species per net) than 1990 (mean 2.25 species per net). The largest changes in abundance were associated with Lake Whitefish (two individuals in 1990 versus 15 in 2013) and Lake Trout (one in 1990 versus 17 in 2013).

In 2013, the mean age of Little Vermillion Lake Cisco was 1.8 years (range $0-7$ years), and mean total length was $112 \mathrm{~mm}$ (range $54-173 \mathrm{~mm}$ ). Cisco sex ratio was 192 female: 99 male. Ciscoes netted in 1990 were similar in size, with total lengths between 49 and 195 mm (Wain 1993).

\section{Discussion}

Our study indicates that a long-term decline in the abundance and diversity of native fishes in the pelagic zone of Sandybeach Lake has occurred since Rainbow Smelt were introduced. The most notable change from 1990 to 2012 was the absence of Cisco and Emerald Shiner in 2012. Based on the lack of ciscoes in pelagic gill-nets, the small number of old individuals in benthic 

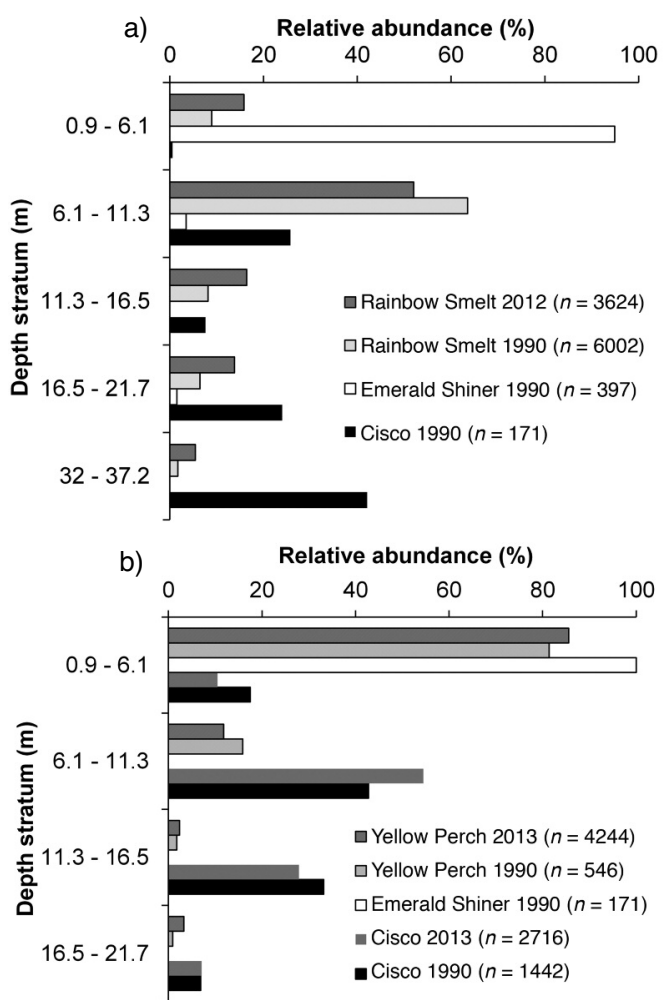

FIGURE 2. Between-year and among-depth-strata variation in the relative abundance (\% caught at each stratum) of four fishes captured in pelagic gill-nets set in Sandybeach Lake (a), where Rainbow Smelt (Osmerus mordax) were present, and Little Vermillion Lake (b), without Rainbow Smelt, northern Ontario. The number of each species captured is given in parentheses. gill-nets, and a severely skewed sex ratio, we expect ciscoes will be extirpated from Sandybeach Lake. In contrast, Cisco was still abundant in Little Vermillion Lake, with the presence of young individuals indicating ongoing recruitment. The severe, long-term decline of ciscoes in Sandybeach Lake is consistent with observations from smaller lakes in Wisconsin (Hrabik et al. 1998).

Although the Laurentian Great Lakes and other large lakes provide sufficient habitat and resource heterogeneity to reduce competition between Rainbow Smelt and native fishes, small lakes provide less opportunity for niche segregation (Rooney and Paterson 2009; Olynuk 2013). Wain (1993) found that Sandybeach Lake ciscoes have a narrower habitat niche (in the presence of abundant Rainbow Smelt) than Cisco in Little Vermillion Lake. Although widely distributed at all depths of Little Vermillion Lake, Cisco was most prevalent in the deep, hypolimnetic waters of Sandybeach Lake. Shifts in the expected vertical distribution of Cisco in the presence of Rainbow Smelt have been observed in other inland lakes (Rudstam and Magnuson 1985). Also, both ciscoes and Rainbow Smelt in Sandybeach Lake primarily fed on the same zooplankton prey, calanoid copepods (Calanoida spp.; Wain 1993). Compared with Little Vermillion Lake, zooplankton abundance in Sandybeach Lake was much lower, especially in the epilimnion and metalimnion where Rainbow Smelt were most abundant (Wain 1993). Therefore, in addition to the substantial potential for larval consumption (Loftus and Hulsman 1986; Myers et al. 2009), Rainbow Smelt likely had a negative impact on Sandybeach Lake ciscoes through competition.

Emerald Shiner was previously abundant in the epilimnion of Sandybeach Lake, but absent in 2012. In the

TABLE 2. Variation in the abundance (CPUE), richness, diversity (Shannon-Weiner index), and dissimilarity (Bray-Curtis measure) of native fish species caught in pelagic gill-nets between years and by depth strata in Sandybeach Lake where Rainbow Smelt (Osmerus mordax) were present and Little Vermillion Lake where they were absent, northern Ontario.

\begin{tabular}{|c|c|c|c|c|c|c|}
\hline Lake & Depth, m & Year & $\begin{array}{l}\text { CPUE, mean } \\
(95 \% \mathrm{CI})\end{array}$ & Richness & $\begin{array}{l}\text { Species diversity } \\
\text { index }(95 \% \mathrm{CI})\end{array}$ & Dissimilarity \\
\hline \multirow[t]{10}{*}{ Sandybeach } & \multirow[t]{2}{*}{$0.9-6.1$} & 1990 & $4.11(3.06-5.08)$ & 5 & $0.51(0.41-0.56)$ & \multirow[t]{2}{*}{0.83} \\
\hline & & 2012 & $0.71(0.51-0.91)$ & 6 & $0.68(0.47-0.85)$ & \\
\hline & \multirow[t]{2}{*}{$6.1-11.3$} & 1990 & $1.90(0.00-2.22)$ & 6 & $0.83(0.70-0.94)$ & \multirow[t]{2}{*}{0.94} \\
\hline & & 2012 & $0.35(0.23-0.48)$ & 5 & $1.40(1.20-1.51)$ & \\
\hline & \multirow[t]{2}{*}{$11.3-16.5$} & 1990 & $0.23(0.11-0.36)$ & 1 & 0.00 & \multirow[t]{2}{*}{1.00} \\
\hline & & 2012 & $0.17(0.09-0.25)$ & 4 & $0.93(0.76-1.22)$ & \\
\hline & \multirow[t]{2}{*}{$16.5-21.7$} & 1990 & $0.85(0.31-1.30)$ & 4 & $0.62(0.32-0.86)$ & \multirow[t]{2}{*}{0.98} \\
\hline & & 2012 & $0.46(0.24-0.68)$ & 3 & $0.51(0.28-0.78)$ & \\
\hline & \multirow[t]{2}{*}{$32.0-37.2$} & 1990 & $1.44(0.79-2.15)$ & 4 & $0.26(0.07-0.45)$ & \multirow[t]{2}{*}{1.00} \\
\hline & & 2012 & 0.00 & 0 & - & \\
\hline \multirow[t]{8}{*}{ Little Vermillion } & \multirow[t]{2}{*}{$0.9-6.1$} & 1990 & $17.20(15.70-18.70)$ & 6 & $1.27(1.22-1.33)$ & \multirow[t]{2}{*}{0.63} \\
\hline & & 2013 & $49.20(39.70-58.70)$ & 8 & $0.29(0.27-0.32)$ & \\
\hline & \multirow[t]{2}{*}{$6.1-11.3$} & 1990 & $11.40(8.80-14.00)$ & 4 & $0.62(0.55-0.69)$ & \multirow[t]{2}{*}{0.32} \\
\hline & & 2013 & $20.60(17.70-23.50)$ & 6 & $0.62(0.59-0.65)$ & \\
\hline & \multirow[t]{2}{*}{$11.3-16.5$} & 1990 & $11.10(9.00-13.20)$ & 3 & $0.09(0.05-0.14)$ & \multirow[t]{2}{*}{0.18} \\
\hline & & 2013 & $9.80(8.40-11.10)$ & 4 & $0.43(0.37-0.48)$ & \\
\hline & \multirow[t]{2}{*}{$16.5-21.7$} & 1990 & $4.50(3.80-5.20)$ & 5 & $0.25(0.15-0.36)$ & \multirow[t]{2}{*}{0.36} \\
\hline & & 2013 & $2.50(2.00-3.00)$ & 5 & $0.67(0.52-0.80)$ & \\
\hline
\end{tabular}

Note: $\mathrm{CI}=$ confidence interval, $\mathrm{CPUE}=$ catch-per-unit effort, individuals $/ \mathrm{h}$. 
Laurentian Great Lakes, Emerald Shiner populations declined after the invasion and proliferation of invasive Alewife (Alosa pseudoharengus (Wilson, 1811)) and Rainbow Smelt, likely resulting from competition and predation (Crowder 1980). The pelagic eggs and larvae of Emerald Shiner are vulnerable to predation (Rooney and Paterson 2009), and adults have been found to comprise a substantial component of the diet of Rainbow Smelt in inland lakes (MacCrimmon and Pugsley 1979; Evans and Loftus 1987). However, in this study, a strong link between Rainbow Smelt and the absence of Emerald Shiner cannot be made, as Emerald Shiner was also absent from Little Vermillion Lake in 2013. Factors responsible for the species' absence from Little Vermillion Lake are unknown.

Based on the lack of juvenile whitefish in 1990, Wain (1993) suggested that recruitment failure was occurring in Sandybeach Lake. Rainbow Smelt introductions can negatively affect Lake Whitefish recruitment through predation on larval whitefish (Loftus and Hulsman 1986). In contrast to our experience at Little Vermillion Lake, we did not capture any Lake Whitefish from the pelagic zone of Sandybeach Lake. Lake Whitefish captured with benthic gill-nets in 2012 were larger (total length 477-618 $\mathrm{mm}$ ) than whitefish captured in 1990 (total length 402-497 mm). These observations indicate that whitefish recruitment remains poor.

Differences in gill-raker count and jaw morphology provide evidence that both Cisco and the threatened Shortjaw Cisco are present in Sandybeach Lake. However, recent genetic-based research indicates that Shortjaw Cisco in inland Canadian lakes should be interpreted as a divergent morph of the ancestral Cisco, rather than a separate species (Turgeon et al. 2016). Accordingly, the authors recommend a lake-specific conservation approach that considers local diversity of cisco morphs. For Sandybeach Lake, the long-term consequence of the Rainbow Smelt introduction appears to be imminent extirpation of both morphs. Based on the results of this study and Hrabik et al. (1998), any future introduction of Rainbow Smelt into small, deep Ontario lakes with multiple cisco morphs (e.g., Loonhaunt Lake in northwestern Ontario and White Partridge Lake in Algonquin Provincial Park) would likely have similar impacts. Where already established, Rainbow Smelt may disrupt the ecological conditions that maintain reproductive isolation between sympatric cisco morphs. In Norway, the introduction of Vendace (Coregonus albula (L., 1758)) - an efficient zooplanktivore resulted in the rapid collapse of a genetically isolated, European Whitefish species-pair (Coregonus lavaretus (L., 1758)) into a single population (Bhat et al. 2014). Considering the presence of Rainbow Smelt in most lakes with multiple cisco morphs, future research on the risk of "speciation in reverse" would help to assess the long-term prospects for this component of Canadian aquatic biodiversity.

\section{Acknowledgements}

This research was supported by provincial and federal species at risk program funds. Sarah Hogg, Mike Parna, D. Remnant, and Matt Sweeting assisted with netting. The operators of the Pine Cliff Lodge provided access to Sandybeach Lake. Otolith interpretation was done at the Northwest Biodiversity and Monitoring Ageing Lab. Previous versions of the manuscript were improved with comments from Sarah Hogg and three anonymous reviewers.

\section{Literature Cited}

Bhat, S., P.-A., Amundsen, R. Knudsen, K. Oystein Gjelland, S.-E. Fevolden, L. Bernatchez, and K. Præbel. 2014. Speciation reversal in European Whitefish (Coregonus lavaretus (L.)) caused by competitor invasion. PLOS One 9: e91208.

Campbell, K. B., A. J. Derksen, R. A. Remnant, and K. W. Stewart. 1991. First specimens of Rainbow Smelt, $O s$ merus mordax, from Lake Winnipeg. Canadian FieldNaturalist 105: 568-570.

COSEWIC (Committee on the Status of Endangered Wildlife in Canada). 2015. Wildlife Species Search. Committee on the Status of Endangered Wildlife in Canada. Accessed 17 May 2016. http://www.cosewic.gc.ca/eng/sct1 /searchform_e.cfm.

Clarke, K. R. 1993 . Non-parametric multivariate analysis of changes in community structure. Australian Journal of Ecology 18: 117-143.

Crowder, L. B. 1980. Alewife, Rainbow Smelt, and native fishes in Lake Michigan: competition or predation? Environmental Biology of Fishes 5: 225-233.

Dextrase, A. J., and N. E. Mandrak. 2006. Impacts of alien invasive species on freshwater fauna at risk in Canada. Biological Invasions 8: 13-24.

Etnier, D. A., and C. E. Skelton. 2003. Analysis of three cisco forms (Coregonus, Salmonidae) from Lake Saganaga and adjacent lakes near the Minnesota/Ontario border. Copeia 2003: 739-749.

Evans, D. O., and D. H. Loftus. 1987. Colonization of inland lakes in the Great Lakes region by rainbow smelt Osmerus mordax: their freshwater niche and effects on indigenous fishes. Canadian Journal of Fisheries and Aquatic Sciences 44 (Supplement 2): 249-266.

Franzin, W. G., B. A. Barton, R. A. Remnant, D. B. Wain, and S. J. Pagel. 1994. Range extension, present and potential distribution and possible effects of rainbow smelt in Hudson Bay drainage waters of northwestern Ontario, Manitoba, and Minnesota. North American Journal of Fisheries Management 14: 65-76.

Hammer, Ø., D. A. T. Harper, and P. D. Ryan. 2001. PAST: paleontological statistics software package for education and data analysis. Palaeontologia Electronica 4: 1-9.

Hrabik, T. R., J. Magnuson, and A. S. McLain. 1998. Predicting the effects of rainbow smelt on native fishes in small lakes: evidence from long-term research on two lakes. Canadian Journal of Fisheries and Aquatic Sciences 55: 1364-1371.

Hubbs, C. L., K. F. Lagler, and G. R. Smith. 2004. Fishes of the Great Lakes Region. University of Michigan, Ann Arbor, Michigan, USA. 
Legendre, P., and L. Legendre. 1998. Numerical Ecology. Second Edition. Elsevier Science B.V., Amsterdam, Netherlands.

Loftus, D. H., and P. F. Hulsman. 1986. Predation on larval lake whitefish (Coregonus clupeaformis) and lake herring (C. artedi) by adult rainbow smelt (Osmerus mordax). Canadian Journal of Fisheries and Aquatic Sciences 43: 812-818.

MacCrimmon, H. R., and R. W. Pugsley. 1979. Food and feeding of the Rainbow Smelt (Osmerus mordax) in Lake Simcoe, Ontario. Canadian Field-Naturalist 93: 266-271.

Mercado-Silva, N., J. D. Olden. J. T. Maxted, T. R. Hrabik, and M. J. Vander Zanden. 2006. Forecasting the spread of invasive Rainbow Smelt in the Laurentian Great Lakes region of North America. Conservation Biology 20: 17401749.

MNRF (Ministry of Natural Resources and Forestry). 2016. Species at Risk in Ontario (SARO) List. Accessed 1 June 2016. http://www.ontario.ca/environment-and-energy /species-risk-ontario-list.

Myers, J. T., M. L. Jones, J. D. Stockwell, and D. L. Yule. 2009. Reassessment of the predatory effects of Rainbow Smelt on ciscoes in Lake Superior. Transactions of the American Fisheries Society 138: 1352-1368.

Muir, A. M., M. P. Ebener, H. X. He, and J. E. Johnson. 2008. A comparison of the scale and otolith methods of age estimation for Lake Whitefish in Lake Huron. North American Journal of Fisheries Management 28: 625-635.

Olynuk, A. J. 2013. A diet analysis of two zooplanktivores, the non-indigenous Rainbow Smelt (Osmerus mordax) and the native Cisco (Coregonus artedi). M.Sc. thesis, University of Manitoba, Winnipeg, Manitoba, Canada.
Rooney, R. C., and M. J. Paterson. 2009. Ecosystem effects of Rainbow Smelt (Osmerus mordax) invasions in inland lakes: a literature review. Canadian Technical Report of Fisheries and Aquatic Sciences 2845.

Rudstam, L. G., and J. J. Magnuson. 1985. Predicting the vertical distribution of fish populations: analysis of cisco, Coregonus artedii, and yellow perch, Perca flavescens. Canadian Journal of Fisheries and Aquatic Sciences 42: $1178-1188$.

Scott, W. B., and E. J. Crossman. 1973. Freshwater Fishes of Canada. Bulletin 184. Fisheries Research Board of Canada, Ottawa, Ontario, Canada.

Shortjaw Cisco Recovery Team (SCRT). 2005. Recovery strategy for the Shortjaw Cisco (Coregonus zenithicus) in Canada [draft]. Fisheries and Oceans Canada, Winnipeg, Manitoba, Canada.

Sokal, R. R., and F. J. Rohlf. 1995. Biometry, Third Edition. W. H. Freeman and Company, New York, New York, USA.

Turgeon, J., S. M. Reid, A. Bourret, T. C. Pratt, J. D. Reist, A. M. Muir, and K. L. Howland. 2016. Morphological and genetic variation in Cisco (Coregonus artedi) and Shortjaw Cisco (C. zenithicus): evidence for repeated sympatric origin of Shortjaw Cisco in deep inland lakes. Conservation Genetics 17: 45-56.

Wain, D. B. 1993. The effects of introduced rainbow smelt (Osmerus mordax) on the indigenous pelagic fish community of an oligotrophic lake. M.Sc. thesis, University of Manitoba, Winnipeg, Manitoba, Canada.

Received 20 June 2016

Accepted 11 October 2016 